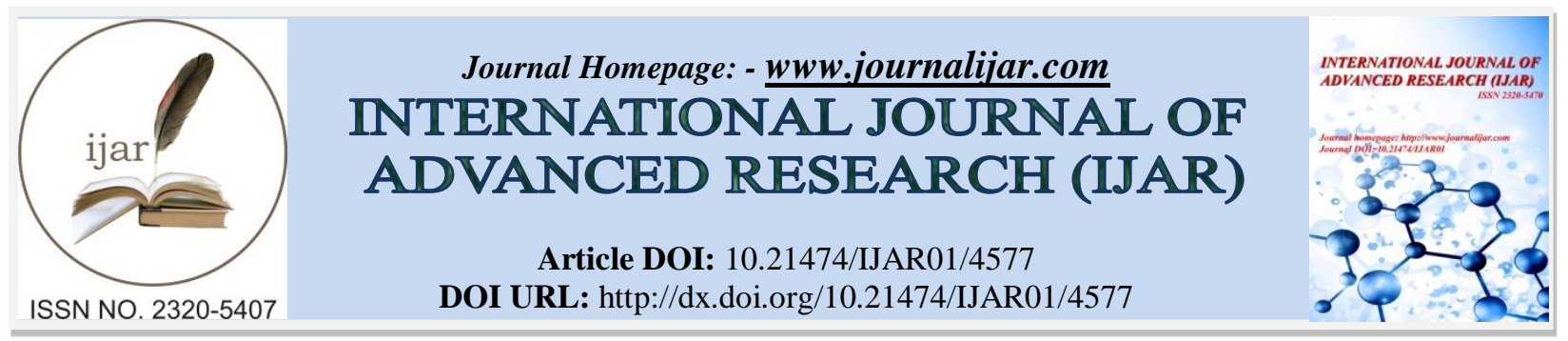

RESEARCH ARTICLE

\title{
ASSESSMENT OF PHYSICO CHEMICAL, MICROBIAL CHARACTERISTICS AND HEAVY METALS CONTAMINATION AT E WASTE DUMPING SITES AT AHMEDABAD, GUJARAT.
}

\author{
Pankaj Kumar and * M. H. Fulekar.
}

School of Environment and Sustainable Development, Central University of Gujarat, Gandhinagar, Gujarat, India.

\section{Manuscript Info}

\section{Manuscript History}

Received: 23 April 2017

Final Accepted: 25 May 2017

Published: June 2017

Key words:-

Electronic, e-waste, hazards, heavy metals accumulation, bray-cluster analysis

\section{Abstract}

Electronic waste, or e-waste, is a growing concern and in addition a commercial chance of increasing centrality, given the volumes of ewaste being produced and the substance of both dangerous furthermore, profitable materials in them. The portion including iron, copper, aluminum, gold and other metals in e-waste is more than $60 \%$, while contaminations include $2.70 \%$. E-waste incorporates a broad and growing range of used electronic devices like television, computer, refrigerator, air conditioner, and mobile phones etc., which contain various types of toxic materials that poses both occupational and environmental health hazards apart from polluting the adjoining environment severely. The present study was carried out to assess the effect of e-waste on soil physico-chemical characteristics and heavy metals contamination from these materials. The soil samples were collected from e-waste contaminated sites in Ahmedabad. Three different sites were selected and soil sampling was carried out and processed for analyzing the various physico-chemical properties like Temperature, pH, Electrical conductivity, Soil moisture, Water holding capacity, Chloride, Alkalinity, Acidity, Sulphate, Organic matter, Organic carbon, Total nitrogen, Available phosphorus, Potassium, as per the Standard methods. The result showed that soil had higher $\mathrm{pH}$ regime. Soil samples were also found to contain heavy metals like $\mathrm{Cu}, \mathrm{Zn}, \mathrm{Ni}, \mathrm{Pb}$, and As. The order of occurrence of heavy metals in soil was $\mathrm{Zn}>\mathrm{Cu}>\mathrm{Pb}>\mathrm{Ni}$. The study indicates the hazardous effect of e-waste on the soil profile.

Copy Right, IJAR, 2017,. All rights reserved.

\section{Introduction:-}

The rapid industrial development and urbanization have significantly expanded the era of wastes and new sorts of toxins. Modern insurgency took after by the advances in data innovation amid the most recent century has drastically changed the individual's way of life. In spite of the fact that this advancement has helped mankind, bungle has prompted to new issues of defilement and contamination. For instance, (PCs) contain certain parts, which are profoundly dangerous, for example, chlorinated and brominated substances, lethal gases, poisonous metals, naturally dynamic materials, acids, plastics and plastic added substances. The dangerous constituent of these materials represents a natural and health risk. Far reaching contamination by substantial metals created from different modern and rural exercises affect human health and biological communities (Nriagu and Pacyna 1988).

Corresponding Author:- M. H. Fulekar.

Address:- School of Environment and Sustainable Development, Central University of Gujarat, 
E-waste has developed into a complex social and worldwide problem with deep-rooted issues. E-waste is developing exponentially as of late in light of the fact that the business sectors in which these items are created are likewise developing quickly. Activities regarding electronic waste (e-waste) are developing as a worldwide worry as they can add to the arrival of steady contaminated substances (PTSs) into our surroundings and along these lines into the food web. E-waste issue is of worldwide concern due to the way of generation and transfer of waste in a globalized world. Like hazardous waste, the issue of e-waste has turned into a quick and long term concern as its unregulated gathering and reusing can prompt to major natural issues threatening human health.

Heavy metals polluted soil from industrial waste; electronic waste and so on the other hand represents a genuine danger to both man and animals in the environment if not properly remediated to the harmless level. Natural contamination by heavy metals which are discharged into the environment through different anthropogenic exercises, for example, mining, energy and fuel generation, electroplating, wastewater sewage treatment and agriculture is one of the world's major natural issues. Heavy metals or trace metals indicate to a huge group of trace components which are both industrially and naturally essential. At first, heavy metals are normally present in soils as natural component, but as of now, the presence of heavy metals in the environment has enhanced due to human activities. This is a far reaching issue the world over where the unreasonable concentration of substantial metals, for example, $\mathrm{Pb}, \mathrm{Zn}, \mathrm{Cr}, \mathrm{Cu}, \mathrm{Cd}, \mathrm{Hg}$, and $\mathrm{As}$ can be found in soils. Therefore the present research study was undertaken, to investigate the soil physico-chemical properties, heavy metal concentration and microbial characterization of electronic waste contaminated sites.

\section{Materials and Methods:-}

\section{Study Area:-}

Ahmedabad located on the banks of the river Sabarmati in the northern part of Gujarat and the western part of India at $23.03^{\circ} \mathrm{N} 72.58^{\circ} \mathrm{E}$ spanning an area of $464 \mathrm{~km}^{2}$. An initial survey was conducted for classifying e-waste dumping sites at Ahmedabad with the support of information from the Gujarat Pollution Control Board. The present study was conducted at three e-waste recycling sites located near Kalupur, Ahmedabad. (Fig 1)

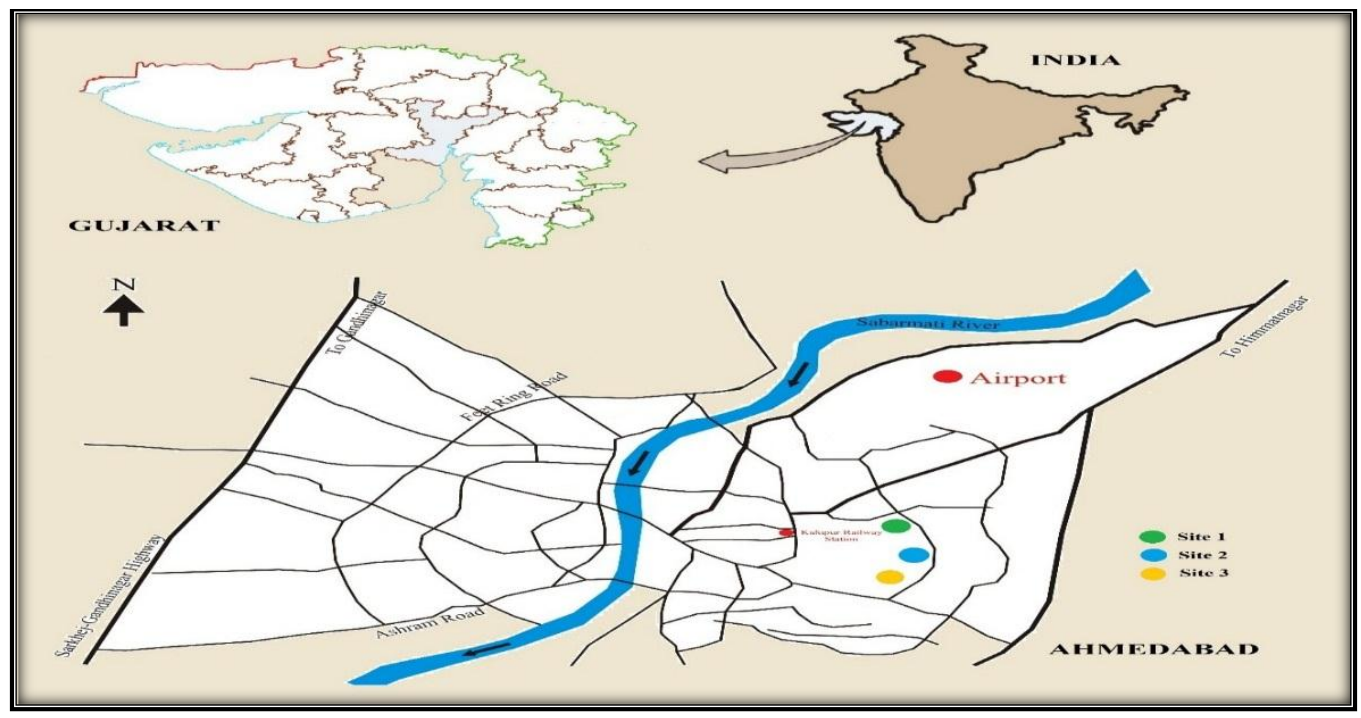

Fig 1:- Study Area Map

Collection of E-waste contaminated soil samples:-

Samples were collected from the surface $(0-15 \mathrm{~cm})$ and subsurface $(15-30 \mathrm{~cm})$ from three different sites (I-III). This area is characterized by having loamy soil. Each sample used as a representative of that particular site and experiments were performed in duplicates. All of the surface soils were collected using acid-washed stainless steel scoops and were immediately transferred in airtight zip lock bags.

\section{Physico chemical characterization of E-waste contaminated soil Samples:-}

Soil samples collected from all three sites were examined for various physico-chemical parameters like $\mathrm{pH}$, Electrical conductivity, Soil moisture, Water holding capacity, Chloride, Alkalinity, Acidity, sulfate (Turbidimetric 
method), Organic matter, Organic carbon (Walkley and Black, 1934), Total nitrogen (Kjeldhal method), Available phosphorus (Olsen, 1954), Potassium, analysis were performed as per the Standard methods. The temperature was examined on the sample collection point using soil thermometer.

Analysis of Heavy Metals in E-waste Contaminated Soil:-

Soil samples were air dried at room temperature. After 7 days samples were crushed and passed through $2 \mathrm{~mm}$ mesh sieve. About $3 \mathrm{gm}$. of soil sample was weighed in acid washed beaker. The samples were digested by the addition of $20 \mathrm{ml}$ aqua regia $(\mathrm{HCl}$ and $\mathrm{HNO} 3,3: 1)$ and $10 \mathrm{ml}$ of $10 \% \mathrm{H} 2 \mathrm{O} 2$ and processed as per standard procedure and analyzed for heavy metals using AAS (Atomic Absorbance Spectrophotometer).

\section{Specification of Fungi and Bacteria Counts:-}

The soil samples were analyzed for microbial characteristics by counting the number of visible spores/colonies that appeared on the plates. Calculation of spore/colony forming unit (sfu/cfu) per $\mathrm{ml}$ for fungi and bacteria was based on the volume of the sample used. (Orimoloye et al., 2016).

\section{Statistical Analysis:-}

The data collected through the experiments has been classified and tabulated into tables for analysis purpose. The correlation coefficient matrix normally used to measure the degree of correlation between the logarithms of the elemental concentrations (Garcia and Millán 1998; Reddy, M. Vikram et al., 2013). Correlation analysis was done to find out the heavy metals characteristics in the contaminated soil samples. Bray-Cluster analysis was done to obtain the similarity among the three different e-waste contaminated sites based on their physico-chemical properties.

\section{Results and Discussion:-}

Table 1 shows the physicochemical characteristics of the contaminated soil samples with differences in all the determined parameters, while Table 2 shows the correlation matrix among the physical parameters of the contaminated soil samples. Correlation matrix among the chemical properties of e-waste contaminated soil samples were presented in Table 3. Similarity matrix among the different sampling sites was shown in Table 4. Concentration of different heavy metals found in the e-waste contaminated soil samples were displayed in Table 5. Table 6 shows the measurement of the degree of correlation among the heaviest metals concentrations. The maximum recommended limits for heavy metals in soil FEPA (Federal Environmental Protection Agency) are presented in Table 7. Microbial characterization of e-waste contaminated soil samples are shown in Table 8.

Table 1:- Physico-chemical characterization of $E$ waste contaminated soil

\begin{tabular}{|c|c|c|c|}
\hline Parameters & $\begin{array}{c}\text { Site 1 } \\
\text { Mean } \pm \text { Sd }\end{array}$ & $\begin{array}{c}\text { Site 2 } \\
\text { Mean } \pm \text { Sd }\end{array}$ & $\begin{array}{c}\text { Site 3 } \\
\text { Mean } \pm \text { Sd }\end{array}$ \\
\hline Colour & Black & Dark brown & Black \\
\hline Texture & Sandy-loamy & Sandy-loamy & Sandy-loamy \\
\hline Temperature $\left({ }^{\circ} \mathrm{C}\right)$ & $22.20 \pm 0.42$ & $21.68 \pm 0.79$ & $26.5 \pm 0.73$ \\
\hline $\mathrm{pH}$ & $8.24 \pm 0.15$ & $8.37 \pm 0.06$ & $8.074 \pm 0.17$ \\
\hline EC $(\mu \mathrm{s} / \mathrm{cm})$ & $200.40 \pm 11.04$ & $404.60 \pm 37.35$ & $971 \pm 22.75$ \\
\hline Soil moisture $(\%)$ & $2.59 \pm 0.40$ & $15.46 \pm 0.96$ & $2.062 \pm 0.65$ \\
\hline W.H.C. $(\%)$ & $48.60 \pm 3.71$ & $50.20 \pm 4.87$ & $37.6 \pm 3.51$ \\
\hline Organic Carbon $(\%)$ & $1.52 \pm 0.31$ & $2.62 \pm 0.51$ & $2.054 \pm 0.17$ \\
\hline Organic Matter $(\%)$ & $2.60 \pm 0.53$ & $4.51 \pm 0.88$ & $3.53 \pm 0.30$ \\
\hline Chloride $(\%)$ & $0.06 \pm 0.01$ & $0.13 \pm 0.01$ & $0.128 \pm 0.04$ \\
\hline Calcium $(\%)$ & $4.232 \pm 0.20$ & $3.31 \pm 0.308$ & $2.438 \pm 0.184$ \\
\hline Sodium $(\%)$ & $0.552 \pm 0.04$ & $0.462 \pm 0.035$ & $0.76 \pm 0.038$ \\
\hline Magnesium $(\%)$ & $0.74 \pm 0.03$ & $0.535 \pm 0.051$ & $0.857 \pm 0.025$ \\
\hline Alkalinity $(\mathrm{mg} / \mathrm{lit})$ & $73.76 \pm 1.94$ & $64.15 \pm 2.91$ & $51.35 \pm 2.07$ \\
\hline Acidity $(\mathrm{mg} / \mathrm{lit})$ & $44.71 \pm 1.16$ & $40.81 \pm 0.96$ & $36.874 \pm 1.20$ \\
\hline Sulphate $(\mathrm{mg} / \mathrm{kg})$ & $31.22 \pm 2.71$ & $51.87 \pm 8.41$ & $75.842 \pm 13.12$ \\
\hline Potassium $(\mathrm{mg} / \mathrm{kg})$ & $39.68 \pm 2.08$ & $30.58 \pm 0.94$ & $45.07 \pm 0.64$ \\
\hline Nitrogen $(\mathrm{mg} / \mathrm{kg})$ & $0.13 \pm 0.08$ & $0.23 \pm 0.04$ & $0.1765 \pm 0.01$ \\
\hline A. Phosphorus $(\mathrm{mg} / \mathrm{kg})$ & $0.93 \pm 0.14$ & $1.00 \pm 0.19$ & $1.06 \pm 0.08$ \\
\hline
\end{tabular}


Table 2:- Correlation matrix among the physical properties of e-waste contaminated sites

\begin{tabular}{|c|c|c|c|c|c|}
\hline & Temperature & $\mathrm{pH}$ & EC & Soil moisture & W.H.C. \\
\hline Temperature & 1 & & & & \\
\hline $\mathrm{pH}$ & -0.94 & 1 & & & \\
\hline EC & 0.94 & -0.76 & 1 & & \\
\hline Soil moisture & -0.61 & 0.85 & -0.30 & 1 & \\
\hline W.H.C. & -1.00 & 0.94 & -0.93 & 0.63 & 1 \\
\hline
\end{tabular}

\section{$>$ EC - Electrical Conductivity, WHC - Water Holding Capacity}

Table 3:- Correlation matrix among the chemical properties of e-waste contaminated sites

\begin{tabular}{|c|c|c|c|c|c|c|c|c|c|c|c|c|}
\hline & O.C. & O.M. & $\begin{array}{l}\text { Chlor } \\
\text { ide }\end{array}$ & $\mathrm{Ca}$ & $\mathrm{Na}$ & $\mathrm{Mg}$ & $\begin{array}{l}\text { Alka } \\
\text { linity }\end{array}$ & $\begin{array}{c}\text { Acidi } \\
\text { ty }\end{array}$ & $\begin{array}{c}\text { Sulphat } \\
\text { e }\end{array}$ & Potassium & T.N & $\begin{array}{l}\text { A. } \\
\text { P }\end{array}$ \\
\hline O.C. & 1 & & & & & & & & & & & \\
\hline O.M. & 1.00 & 1 & & & & & & & & & & \\
\hline Chloride & 0.87 & 0.87 & 1 & & & & & & & & & \\
\hline $\mathrm{Ca}$ & -0.50 & -0.50 & -0.86 & 1 & & & & & & & & \\
\hline $\mathrm{Na}$ & -0.31 & -0.31 & 0.20 & -0.67 & 1 & & & & & & & \\
\hline $\mathrm{Mg}$ & -0.64 & -0.64 & -0.18 & -0.34 & 0.93 & 1 & & & & & & \\
\hline Alkalinity & -0.41 & -0.41 & -0.81 & 1.00 & -0.74 & -0.43 & 1 & & & & & \\
\hline Acidity & -0.48 & -0.48 & -0.85 & 1.00 & -0.68 & -0.36 & 1.00 & 1 & & & & \\
\hline Sulphate & 0.45 & 0.45 & 0.83 & -1.00 & 0.71 & 0.40 & -1.00 & -1.00 & 1 & & & \\
\hline Potassium & -0.63 & -0.63 & -0.17 & -0.35 & 0.93 & 1.00 & -0.44 & -0.37 & 0.41 & 1 & & \\
\hline T.N. & 1.00 & 1.00 & 0.86 & -0.48 & -0.33 & -0.66 & -0.39 & -0.46 & 0.43 & -0.65 & 1 & \\
\hline A.P. & 0.52 & 0.53 & 0.88 & -1.00 & 0.65 & 0.32 & -0.99 & -1.00 & 1.00 & 0.33 & 0.50 & 1 \\
\hline
\end{tabular}

OC- Organic Carbon, OM - Organic Matter, TN - Total Nitrogen, AP - Available Phosphorus, Ca - Calcium, Na Sodium, Mg - Magnesium

Bray Cluster Analysis:-

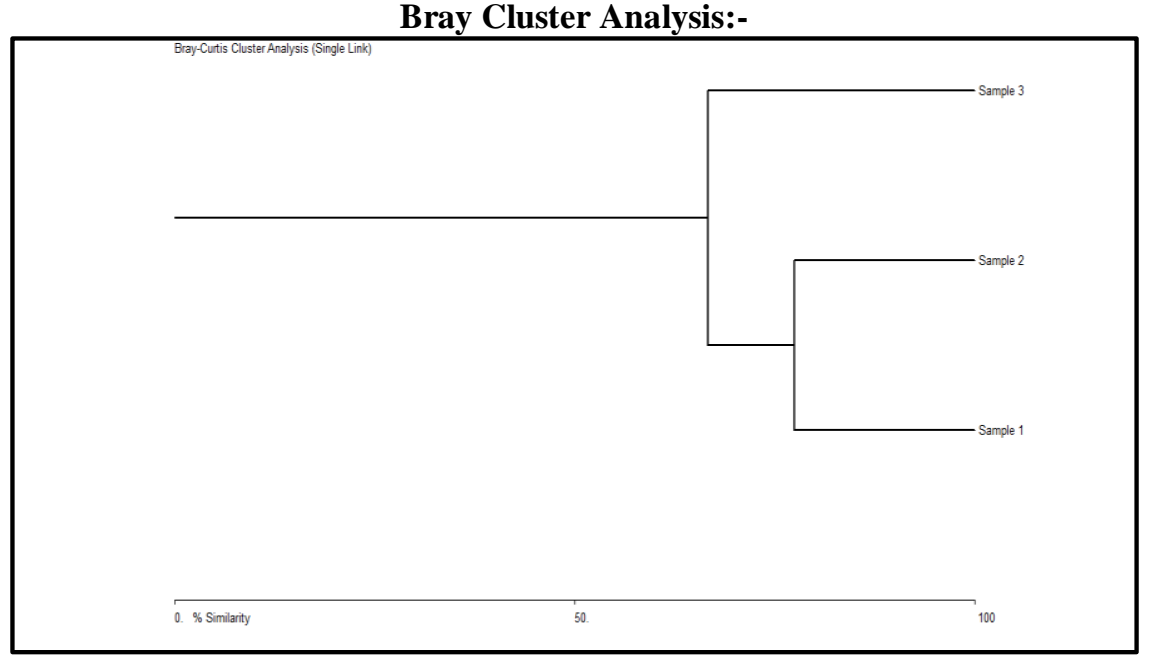

Fig 2:- Bray - Cluster diagram based on the Curtis cluster analysis of different physico-chemical properties among different sampling sites

Table 4:- Similarity Matrix among the different sampling sites

\begin{tabular}{|c|c|c|c|}
\hline & Site 1 & Site 2 & Site 3 \\
\hline Site 1 & $*$ & 77.4202 & 50.1759 \\
\hline Site 2 & $*$ & $*$ & 66.6367 \\
\hline Site 3 & $*$ & $*$ & $*$ \\
\hline
\end{tabular}


Table 5:- Heavy metals concentration present at E-waste contaminated soil

\begin{tabular}{|c|c|c|c|c|}
\hline Metals & Site 1 & Site 2 & Site 3 & Mean \pm Sd \\
\hline Zinc & 156.0 & 141.6 & 124.8 & $140.8 \pm 15.6$ \\
\hline Copper & 116.4 & 124.8 & 134.4 & $125.2 \pm 9.0$ \\
\hline Lead & 66.8 & 44.7 & 86.4 & $66.0 \pm 20.9$ \\
\hline Nickel & 7.6 & 2.0 & 10.0 & $6.5 \pm 4.1$ \\
\hline Arsenic & ND & ND & ND & ND \\
\hline
\end{tabular}

ND - Not detected

Table 6:- Correlation matrix among the heavy metals at E-waste contaminated sites

\begin{tabular}{|c|c|c|c|c|}
\hline & $\mathrm{Zn}$ & $\mathrm{Cu}$ & $\mathrm{Pb}$ & $\mathrm{Ni}$ \\
\hline $\mathrm{Zn}$ & 1 & & & \\
\hline $\mathrm{Cu}$ & 0.980 & 1 & 1 & \\
\hline $\mathrm{Pb}$ & 0.931 & 0.935 & 0.970 & 1 \\
\hline $\mathrm{Ni}$ & 0.989 & 0.990 & & \\
\hline
\end{tabular}

Table 7:- Heavy metals maximum recommended limits in soil

\begin{tabular}{|c|c|}
\hline Heavy Metals & Maximum limits in soil $(\mathrm{mg} / \mathrm{kg})$ \\
\hline Lead & $250-500$ \\
\hline Zinc & $300-600$ \\
\hline Nickel & Not available \\
\hline
\end{tabular}

Source- FEPA (Federal Environmental Protection Agency)

Table 8:- Microbial characterization of E-waste contaminated soil samples

\begin{tabular}{|c|c|c|c|}
\hline Microbial Analysis & Site 1 & Site 2 & Site 3 \\
\hline Total Plate Count cfu/gm. & $2.7 \times 10^{-6}$ & $3.8 \times 10^{-5}$ & 2.9 X10 \\
\hline Coliform cfu/gm. & $<10 \mathrm{cfu}$ & $<10 \mathrm{cfu}$ & $<10 \mathrm{cfu}$ \\
\hline E.Coli/gm & Absent & Absent & Absent \\
\hline Salmonella/25 gm & Absent & Present & Present \\
\hline Yeast and Mould Count cfu/gm & $<10 \mathrm{cfu}$ & $<10 \mathrm{cfu}$ & $<10 \mathrm{cfu}$ \\
\hline Staphylococcus aureus cfu/gm & Absent & Absent & Absent \\
\hline Shigella/25gm & Present & Present & Present \\
\hline
\end{tabular}

Physico chemical properties of metals contaminated sites varied significantly. The investigation of the samples reveals some level of compliance with regulated standards and the significant deviations were similarly observed. The differences in colour of the soil samples (Table 1) could be due to variation in the quantity of organic matter and elemental composition of the soil samples. (Wagai et al., 2008). The textural configuration of the soil did not differ significantly with sites. This is probable as soil texture is mainly inherited from the soil forming parental materials. The mean $\mathrm{pH}$ of the soil samples was 8.22. The toxicity of metals is associated with $\mathrm{pH}$. Consequently, in standard, most metallic toxicity studies show acid pHs (Gupta, 1972; Miles and Parker, 1979; Lexmond, 1980; Suresh et al., 1987; Davis-Carter and Shuman, 1993; Watmough and Dickinson, 1995). The solubility and speciation of metal particles are $\mathrm{pH}$ dependent. The specific influence of $\mathrm{pH}$ will depend upon the nutrient solution being utilized and metal being taken into consideration. In widespread, because the $\mathrm{pH}$ increases the concentration of loose metallicion which could remain in answer decreases, and precipitates may be additionally formed. The $\mathrm{pH}$ estimation of soil samples from e-waste dump site could be associated with accumulation of essential metabolites as well as the high mineral substance of the soil. (Ijah and Abioye, 2003).

The soil organic matter (SOM) content of the contaminated soil samples ranged from 2.60 to $4.51 \%$. The fundamentally higher SOM contents of the soil hinders the exercises of the microorganisms required in the natural matter decay in this way collecting more organic matter. The organic matter substance of the soil assumes an essential part in adsorption response in the soil, thereby preventing contaminations from reaching to the natural resources. (Alloway and Aryes, 1997; Puls et al., 1991; Mclean and Bledsoe, 1992).

Moisture content varied with a range from $2-15.46 \%$. Sulphate was present in very high amount $(31.22 \mathrm{mg} / \mathrm{kg}$ $75.84 \mathrm{mg} / \mathrm{kg})$ at all sites. Alkalinity varied from $(51.35 \mathrm{mg} / \mathrm{l}-73.76 \mathrm{mg} / \mathrm{l})$ which could be attributed the $\mathrm{pH}$. 
Electronic scrap has been reported to be alkaline in nature, resulting an increase in the $\mathrm{pH}$ of the medium (Brandl et al., 2001; Ilyas, S. 2007). Available phosphorus content in the contaminated soil sample significantly differed (0.93 to $1.06 \mathrm{mg} / \mathrm{kg}$ ). The lower phosphorous estimation of contaminated soil might be because of the impact of e-waste blazing on this constraining component of the soil. A few measures of phosphorous may have been lost to the air by volatilization during the burning of the e-waste. (DeBano and Klopatek, 1988).

The exchangeable bases $\mathrm{Na}^{+}, \mathrm{K}^{+}, \mathrm{Ca}^{2+}$ and $\mathrm{Mg}^{2+}$ in the soil samples (Table 1) were also analyzed. This could be due to the accumulation of charred biomass. (Abebe and Endalkachew 2011). Reports had also shown that low pH (acidic) favors the abundance of exchangeable anions, but reduced cations, while high $\mathrm{pH}$ (basic) favors the abundance of exchangeable cations, but reduced anions in soils. (Oyedele et al., 2008). Hence, the latter reason could also be responsible for the results of cations in this study.

Cluster analysis was applied to detect spatial similarity of the three sampling sites based on the physico-chemical characteristics of contaminated soil (Table 4). The Bray-Curtis cluster analysis based on the physico-chemical properties of the contaminated soil collected from electronic waste dumping sites resulted in a Dendogram (Fig 2). Dendogram described 2 clusters among the sites, showed that site 1 and site 2 formed one cluster with $77.42 \%$ of similarity. Site 2 and Site 3 formed one cluster with $66.63 \%$ of similarity.

Heavy metal characterization of E-waste contaminated site demonstrated in (Table 5). The e-waste contaminated soil samples were assessed for metal ion concentrations $(\mathrm{Cu}, \mathrm{Ni}, \mathrm{Zn}$ and $\mathrm{Pb})$ using AAS. Arsenic was not detected or in very low ion concentration in all the samples. Zinc varied from (124.8 ppm - $156 \mathrm{ppm})$, Copper (116.4 ppm $134.4 \mathrm{ppm})$, Lead $(44.7 \mathrm{ppm}-86.4 \mathrm{ppm})$ and Nickel $(2 \mathrm{ppm}-10 \mathrm{ppm})$. The occurrence pattern for heavy metals at contaminated site was $\mathrm{Zn}>\mathrm{Cu}>\mathrm{Pb}>\mathrm{Ni}$. The heavy metals analysis of the soil samples also revealed that soil from e-waste dumping site had higher quantities of heavy metals. Of the heavy metals assessed, the lead had the higher quantity $(86.4 \mathrm{mg} / \mathrm{kg})$. This gave a probable understanding of the extent of lead usage in the manufacturing of electrical electronic equipment or gadgets. This was in accordance with the reports of different researchers that lead is the fifth most broadly used metal after iron, aluminium, copper and zinc. It is generally used in the electrical and electronics industry in solder, lead-acid batteries, electronic components, cable sheathing, in the glass of cathode ray tubes. Lead and the other heavy metals in this research are known to be ecologically contaminants and are toxic to living cells. (Grant and Goldizen, 2013).

Nguyen Ngoc Ha et al., (2009) reported a research study on e-waste contaminated site in Bangalore city, India and recorded a very high concentration of different heavy metals concentration of an E-waste recycling unit at slum area (Cr $73 \mathrm{mg} / \mathrm{kg}, \mathrm{Cu} 592 \mathrm{mg} / \mathrm{kg}, \mathrm{Zn} 326 \mathrm{mg} / \mathrm{kg}, \mathrm{Cd} 2.33 \mathrm{mg} / \mathrm{kg}, \mathrm{Hg} 1.8 \mathrm{mg} / \mathrm{kg}, \mathrm{Pb} 297 \mathrm{mg} / \mathrm{kg}$ ). And concentration at city recycling unit (Cr $57 \mathrm{mg} / \mathrm{kg}, \mathrm{Cu} 22.8 \mathrm{mg} / \mathrm{kg}, \mathrm{Zn} 41 \mathrm{mg} / \mathrm{kg}, \mathrm{Cd} 0.165 \mathrm{mg} / \mathrm{kg}, \mathrm{Hg} 0.05 \mathrm{mg} / \mathrm{kg}, \mathrm{Pb} 22.8 \mathrm{mg} / \mathrm{kg}$ ).

Anna Leung et al., (2006) conducted a research study at an electronic waste recycling site at Guiyu, southeast China and recorded different heavy metals in very high concentration at

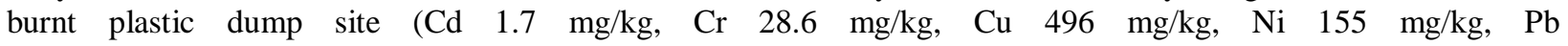
$104 \mathrm{mg} / \mathrm{kg}$, and $\mathrm{Zn} 258 \mathrm{mg} / \mathrm{kg})$. And at printer roller dump site $(\mathrm{Cd} 3.1 \mathrm{mg} / \mathrm{kg}, \quad \mathrm{Cr} 74.9$ $\mathrm{mg} / \mathrm{kg}, \mathrm{Cu} 712 \mathrm{mg} / \mathrm{kg}$, Ni $87.4 \mathrm{mg} / \mathrm{kg}, \mathrm{Pb} 190 \mathrm{mg} / \mathrm{kg}$ ). Brandl et al., (2000) also performed a research study at Ewaste contaminated site for heavy metals $(\mathrm{Al}, \mathrm{Cu}, \mathrm{Pb}, \mathrm{Ni}, \mathrm{Sn}$, and $\mathrm{Zn}$ ) and recorded very high concentration of these metals, (Al 237 g/kg, Cu 80 g/kg, Pb 20 g/kg, Ni 15 g/kg, Sn 23 g/kg, Zn 26 g/kg).

It is inferred from the Table 6 that highly significant positive correlation between the pairs of the heavy metals in the e-waste contaminated soil samples occurred as follows $-\mathrm{Cu}$ with $\mathrm{Zn}(\mathrm{r}=0.98)$, with $\mathrm{Pb}(\mathrm{r}=0.93)$, with $\mathrm{Ni}(\mathrm{r}=0.99)$, $\mathrm{Pb}$ with $\mathrm{Zn}(\mathrm{r}=0.93)$, with $\mathrm{Ni}(\mathrm{r}=0.97)$, with $\mathrm{Pb}(\mathrm{r}=0.87)$, at $\mathrm{p}<0.01$. The above results clearly indicated that the source of origin of heavy metals is probably e-waste.

Physico-chemical characterization of e-waste disposal site showed the presence of macro and micro nutrients. These environmental characteristics support growth of various microbes which was indicated in results of microbiological analysis. The mean total plate counts (TPC) of each soil sample ranged from $2.7 \times 10^{-6}$ to $3.8 \times 10^{-5}$ colony forming units (cfu) per gram of soil presented in table 8. It was found that various bacterial groups were present on different sampling sites. The presence of coliform bacteria, Salmonella, Shigella and Pseudomonas was indicated by initial microbial characterization. E.coli was found to be absent on all the sampling sites. Various microbial species, for example, microorganisms, fungi are known to be appropriate for adsorbing heavy metals on their surface and 
additionally aggregating inside their structure (Campbell and Martin, 1990; Luef, 1991; Mitani and Misic, 1991; Vinita and Radhanath, 1992). It has been shown that bacteria and fungi isolated from polluted environment are frequently tolerant to higher levels of metals than those isolated from unpolluted areas and that tolerant microorganisms are found at higher frequencies in polluted habitats. It has been demonstrated that microscopic organisms and fungi isolated from contaminated environment are as often as possible tolerant to larger amounts of metals than those confined from unpolluted ranges and that tolerant microorganisms are found at higher frequencies in contaminated natural surroundings (Arnebrant et al., 1987; Baath, 1989; Huysman et al., 1994).

\section{Conclusion:-}

E-waste is a developing issue, driven by the quickly expanding amounts of complex end-of-life electronic hardware. The worldwide level of production, utilization and reusing incites extensive streams of both lethal and important substances. E-waste has been one of the fastest growing waste streams in the world. With the developing industrialization and information technology, the electronic waste is likewise extending. Because of its intricate nature, it is getting to be distinctly hard to oversee it, however, there are sure advances like reusing, burning accessible for treating e -waste. As a result of the absence of social mindfulness about this issue and the weaknesses related to current advancements this waste for the most part wind up in making an issue of the earth and human health. So, a safe and ecofriendly technology is the need of the hour for treating this waste. The present article outlines that e-waste contains various hazardous substances, heavy metals and halogenated compounds are of specific concern. Inappropriate dealing and management of e-waste during reusing and other end-of-life treatment choices may develop conceivably critical dangers to both human health and nature.

\section{References:-}

1. Abebe N, Endalkachew K, 2011. Impact of Biomass Burning on Selected Physicochemical Properties of Nitisol in Jimma Zone, Southwestern Ethiopia. International Research Journal of Agricultural Science and Soil Science. 1(9):394-40. ISSN: 2251-0044.

2. Alloway BJ, Ayres DC, 1997. Chemical Principles of Environmental pollution. Blackie Academic and Professional. pp. 53-359.

3. Anna Leung, Zong Wei Cai, Ming Hung Wong, 2006. Environmental contamination from electronic waste recycling at Guiyu, southeast China. J Mater Cycles Waste Management. 8:21-33.

4. Arnebrant K, Baath E, Nordgren A, 1987. Copper tolerance of micro fungi isolated from polluted and unpolluted forest soil. Mycologia. 79, 890-895.

5. Baath E. 1989. Effects of heavy metals in soil on microbial processes and populations (a review). Water Air Soil Pollution; 47:335-79.

6. Bai Jianfeng, 2009. "Microbiological recovering of metals from printed circuit boards by Acidithiobacillus ferrooxidans", IEEE International Symposium on Sustainable Systems and Technology.

7. Brandl H, Bosshard R, Wegmann M, 2000. Computer-munching microbes: metal leaching from electronic scrap by bacteria and fungi. Hydrometallurgy. 592001 319-326.

8. Brandl H, Bosshard R, Wegmann M, 2001. Computer-munching microbes: metal leaching from electronic scrap by bacteria and fungi. Hydrometallurgy. 59, 319-326.

9. Campbell R. and Martin M H, 1990. Continuous flow fermentation to purify wastewater by the removal cadmium. Water, Air and Soil Pollution. vol. 50, p. 397-408.

10. Chen Fu, Baodan Yang, Jing Ma, Junfeng Qu, and Gangjun Liu, 2016). "Decontamination of electronic wastepolluted soil by ultrasound assisted soil washing", Environmental Science and Pollution Research.

11. Davis-Carter, J.G. and Shuman, L.M, 1993. Influence of texture and pH of kaolinitic soils on zinc fractions and zinc uptake by peanuts. Soil Science. 155, 376-384.

12. DeBano LF, Klopatek JM, 1988. Phosphorus dynamics of pinyon-juniper soils following simulated burning. Soil Science Society of America Journal. ; 52:271-277.

13. Deepmala S, Reddy M, and Dhal S P, 2014. Risk Assessment of Heavy Metals Contamination in Paddy Soil, Plants, and Grains (Oryza sativa L.) at the East Coast of India. BioMed Research International. Volume 2014, Article ID 545473, 11 pages. http://dx.doi.org/10.1155/2014/545473.

14. FEPA (Federal Environmental Protection Agency), 2003. Guidelines and Standards for Environmental Pollution Control in Nigeria.

15. Garcia R, and Millan E, 1998“Assessment of $\mathrm{Cd}, \mathrm{Pb}$ and $\mathrm{Zn}$ contamination in roadside soils and grasses from Gipuzkoa (Spain)," Chemosphere. vol. 37, no. 8, pp. 1615-1625. 
16. Grant K, Goldizen FC, Sly PD, Brune MN, Neira M, van den Berg M, Norman RE, 2013. Health consequences of exposure to e-waste: A systematic review, The Lancet Global Health. 2214-\{109X\}.

17. Gupta U C, 1972. Effects of manganese and lime on yield and on concentration of manganese, molybdenum, boron, copper, and iron in the boot stage tissue of barley. Soil Science. 114, 131-136.

18. Husain, Iman A F, 2011. "Kinetic Study of a Bacterial Consortium Isolated from Soil Contaminated with Crude Oil", Australian Journal of Basic \& Applied Sciences/19918178.

19. Huysman F, Verstraete W, Brookes P C, 1994. Effect of manuring practices and increased copper concentrations on soil microbial populations. Soil Biology Biochemistry. 26, 103-110.

20. Ijah UJJ, Abioye OP, 2003. Assessment of physicochemical and microbiological properties of soil 30 months after kerosene spill. Journal of Research in Science and Management. ; 1(1):24-30.

21. Ilyas S, Munir A A, Shahida B. Niazi, M. Afzal Ghauri, 2007. "Bioleaching of metals from scrap by moderately thermophilic acidophilic bacteria", Hydrometallurgy.

22. Kumar R N, 2011. "An Assessment of seasonal variation and water quality index of Sabarmati River and Kharicut canal at Ahmedabad, Gujarat". Electronic Journal of Environmental, Agricultural \& Food Chemistry/15794377.

23. Lexmond T M, (1980). The effect of soil $\mathrm{pH}$ on copper toxicity to forage maize grown under field conditions. Netherlands Journal of Agricultural Science. 28, 164-183.

24. Lin K L, 2007. "The effect of heating temperature of thin film transistor-liquid crystal display (TFT- LCD) optical waste glass as a partial substitute partial for clay in eco-brick", Journal of Cleaner Production.

25. Luef E, Prey T, and Kubicek C P, 1991. Biosorption of zinc by fungal mycelial wastes. Applied Microbiology and Biotechnology. vol. 34, p. 688-692.

26. McLean J E, Bledsoe B E, 1992. Behaviour of Metals in Soils in groundwater issue: EPA/540/S-92/018. U. S. EPA Robert S. Kerr Environment Research Laboratory, Ada, OK. pp. 1-20.

27. Miles L J and Parker G R, 1979. Heavy metal interaction for Andropogon scoparius and Rudbeckia hirta grown on soil from urban and rural sites with heavy metal additions. Journal of Environmental Quality. 8, 443-449.

28. Mitani T, and Misic D M, 1991. Copper Accumulation by Penicillium sp. Isolated from soil. Soil Science Plant Nutrition. vol. 37, no. 2, p. 347-349.

29. Nriagu J O, and Pacyna J M, 1988. Quantitative assessment of worldwide contamination of air, water and soils by trace metals. Nature. 333, 134-139.

30. Olegario de Campos Junior, Edimar, Boscolli Barbosa Pereira, and Sandra Morelli, 2015. "Monitoring Genotoxicity Potential in the Mumbuca Stream, Minas Gerais, Brazil", Journal of Toxicology and Environmental Health Part A.

31. Olsen S. R, C V, Cole F S, Watanabe, and L A Dean, 1954. Estimation of available phosphorus in soils by extraction with sodium bicarbonate. USDA Circular 939. U.S. Government Printing Office, Washington D.C.

32. Orimoloye M Adedolapo, and A Isaac Sanusi, 2016. "Proliferation of Microorganisms in Acidic Fermentation of Elaeis guineensis L. Waste", Advances in Microbiology.

33. Oyedele D. J, Gasu M B and Awotoye O O, 2008. Changes in soil properties and plant uptake of heavy metals on selected municipal solid waste dump sites in Ile-Ife, Nigeria. African Journal of Environmental Science and Technology Vol. 3 (5), pp. 107-115.

34. Peter O, 2011. "Biological Remediation of Hydrocarbon and Heavy Metals Contaminated Soil", Soil Contamination.

35. Puls R W, Powell R M, Clark D, Paul C J, 1991. Facilitated transport of inorganic contaminants in ground water: Part II. Colloidal transport. EPA/600/M-91/040. U. S. EPA Robert S. Kerr Environmental Resource Laboratory, Ada, OK

36. Reddy M V, Satpathy D, and Dhiviya S K, 2013. "Assessment of heavy metals $(\mathrm{Cd}$ and $\mathrm{Pb})$ and micronutrients $(\mathrm{Cu}, \mathrm{Mn}$, and $\mathrm{Zn}$ ) of paddy (Oryza sativa L.) Field surface soil and water in a predominantly paddy-cultivated area at Puducherry (Pondicherry, India), and effects of the agricultural runoff on the elemental concentrations of a receiving rivulet", Environmental Monitoring and Assessment.

37. Sharma P, Fulekar M H and Pathak B, 2012. E-Waste- A Challenge for Tomorrow. Research Journal of Recent Sciences. ISSN 2277-2502, Vol. 1(3), 86-93.

38. Song, Qingbin, and Jinhui Li, 2014. "Environmental effects of heavy metals derived from the e waste recycling activities in China: A systematic review", Waste Management.

39. Suresh R, Foy C D and Weidner J R, 1987. Effects of excess soil manganese on stomatal function in two soybean cultivars. Journal of Plant Nutrition. 10, 749-760.

40. Tang X, 2010. "Heavy metal and persistent organic compound contamination in soil from Wenling: An emerging e-waste recycling city in Taizhou area, China", Journal of Hazardous Materials. 
41. Uluturhan E, 2011. "Sediment concentrations of heavy metals in the Homa Lagoon (Eastern Aegean Sea): Assessment of contamination and ecological risks", Marine Pollution Bulletin.

42. Vinita V P and Radhanath P D, 1992. Bio recovery of zinc from industrial effluent using native microflora. International Journal of Environmental Studies. vol. 44, p. 251-257.

43. Wagai K H, Mayer L N, Kitayama, Knicker H, 2008. Climate and Parent matter Storage in Surface Soils. A three pool, density approach. Geoderma. 147:23-33.

44. Walkley A, and I A Black, 1934. An examination of Degtjareff method for determining soil organic matter and a proposed modification of the chromic acid titration method. Soil Science. 37:29-37

45. Wang S, Yan W, Chunling L, Jun L, Hua Y, and Gan Z, 2016. "Plant selective uptake of halogenated flame retardants at an e-waste recycling site in southern China", Environmental Pollution.

46. Watmough S A and Dickinson N M, 1995. Dispersal and mobility of heavy metals in relation to tree survival in an aerially contaminated woodland soil. Environmental Pollution. 90, 135-142.

47. WHO, 1989. Environmental health criteria 108: Nickel. International programme on chemical safety. World Health Organization. Available: http: IIwww.inchem.org/document s/ehc.

48. Widmera R, Oswald-Krapf H, Sinha-Khetriwal D, Schnellmann M, Boni H, 2005. Global perspectives on ewaste. Environmental Impact Assessment Review 25, 436- 458. 